\title{
Metabolic Implications of Exposure to Wastewater Effluent in Bluegill Sunfish
}

Sherry N. N. Du ${ }^{\mathrm{a}}$, Jasmine A. Choi ${ }^{\mathrm{a}}$, Erin S. McCallum ${ }^{\mathrm{b}}$, Adrienne R. McLean ${ }^{\mathrm{b}}$, Brittney G. Borowiec $^{\mathrm{a}}$, Sigal Balshine ${ }^{\mathrm{b}}$, and Graham R. Scott ${ }^{\mathrm{a}}{ }^{*}$

aDepartment of Biology, McMaster University, 1280 Main Street West, Hamilton, ON, L8S 4K1, Canada

${ }^{b}$ Department of Psychology, Neuroscience, and Behaviour, McMaster University, 1280 Main Street West, Hamilton, ON, L8S 4K1, Canada

${ }^{*}$ Corresponding author

Email address: scottg2@mcmaster.ca 


\section{Abstract}

2 Effluent from wastewater treatment plants (WWTP) contains a complex mixture of

3 contaminants and is a major worldwide source of aquatic pollution. We examine the effects of

4 exposure to treated effluent from a municipal WWTP on the metabolic physiology of bluegill

5 sunfish (Lepomis macrochirus). We studied fish that were wild-caught or experimentally caged

6 (28 d) downstream of the WWTP, and compared them to fish that were caught or caged at clean

7 reference sites. Survival was reduced in fish caged at the effluent-contaminated site compared

8 those caged at the reference site. Resting rates of $\mathrm{O}_{2}$ consumption $\left(\mathrm{MO}_{2}\right)$ were higher in fish

9 from the contaminated site, reflecting a metabolic cost of wastewater exposure. The increases in

10 routine $\mathrm{MO}_{2}$ did not reduce aerobic scope (difference or quotient of maximal $\mathrm{MO}_{2}$ and resting

$11 \mathrm{MO}_{2}$ ), suggesting that physiological compensations accompanied the metabolic costs of

12 wastewater exposure. Fish exposed to wastewater also had larger hearts and livers. The activity

13 of mitochondrial enzymes (cytochrome c oxidase, citrate synthase) per liver mass was unaltered

14 across treatments, so the increased mass of this organ increased its cumulative oxidative capacity

15 in the fish. Wastewater exposure also reduced glycogen content per liver mass. The effects of

16 caging itself, based on comparisons between fish that were wild-caught or caged at clean sites,

17 were generally subtle and not statistically significant. We conclude that exposure to wastewater

18 effluent invokes a metabolic cost that leads to compensatory physiological adjustments that

19 partially offset the detrimental metabolic impacts of exposure.

21 Keywords: Pharmaceuticals and personal care products; Plasticity; Respiration; Aerobic

22 Capacity; Laurentian Great Lakes; Cootes Paradise Marsh. 


\section{Introduction}

Municipal wastewater treatment plants (WWTP) release a complex mixture of contaminants into aquatic environments, and there is growing concern about the impacts of WWTP effluent on aquatic wildlife (Brooks et al., 2006; Callaghan and MacCormack, 2017; Gros et al., 2010; Kolpin et al., 2002; Marcogliese et al., 2015; Nikolaou et al., 2007; Schultz et al., 2010). Effluent from WWTPs typically contain excess nutrients and a complex mixture of chemicals (e.g., pharmaceuticals and personal care products [PPCPs], pesticides, etc.), metals, and nanomaterials, and can also change the temperature and dissolved oxygen content of receiving waters. Exposure to these stressors in isolation can have a range of disruptive effects on the physiology, health, and behaviour of fish (Bjerselius et al., 2001; Craig et al., 2010; Little and Finger, 1990; Nash et al., 2004; Parrott and Blunt, 2005; Scott and Sloman, 2004). However, less is known about the effects on fish physiology of the complex mixtures of contaminants in wastewater, which can be hard to predict as the effects of individual contaminants interact and are combined with variability in other environmental variables (Hahn, 2011; Mothersill et al., 2007; Noyes et al., 2009).

Recent evidence suggests that fish can suffer an appreciable metabolic cost associated with exposure to WWTP effluent (Du et al., 2018; Mehdi et al., 2018). Resting metabolic rate (measured as $\mathrm{O}_{2}$ consumption rate, $\mathrm{MO}_{2}$ ) was higher in wild rainbow darter (Etheostoma caeruleum) caught downstream of a WWTP in the Grand River watershed (near Waterloo, Canada) than wild darters caught at a clean site upstream (Mehdi et al., 2018). Similarly, we showed that resting $\mathrm{MO}_{2}$ was elevated in bluegill sunfish (Lepomis macrochirus) that were caged for 3 weeks in the effluent-contaminated waters near the Dundas WWTP in Hamilton, Canada, compared to bluegill caged at a clean reference site (Du et al., 2018). However, round goby (Neogobius melanostomus) that were similarly caged near the Dundas WWTP did not exhibit increased $\mathrm{MO}_{2}$ compared to control fish (McCallum et al., 2017), suggesting that some species are more resistant and less likely to suffer a metabolic cost of exposure. In this particular case, the differences in susceptibility between bluegill and round goby are associated with differences in their natural distribution across the gradient of exposure: the abundance of round goby is high near the Dundas WWTP and declines further away, whereas bluegill are most abundant in cleaner sites that are less impacted by effluent (McCallum et al., 2019). 
The metabolic costs of exposure to WWTP effluent could affect health and fitness, and may help explain why some species appear incapable of living in contaminated environments. Increases in resting $\mathrm{MO}_{2}$ tend to amplify food demands, which could place an energy stress on fish that do not meet their increased food needs (Beyers et al., 1999; Metcalfe et al., 2016). Alternatively, metabolic costs of exposure might reduce aerobic scope (the difference/quotient of maximal $\mathrm{MO}_{2}$ and standard $\mathrm{MO}_{2}$ ), dampening the capacity to increase aerobic metabolism to support functions such as locomotion, behaviour, growth, and reproduction, and potentially decreasing fitness (Claireaux and Lefrancois, 2007; Eliason and Farrell, 2016; Plaut, 2001). Consistent with potential metabolic effects of exposure, wastewater effluent has been shown to affect various sub-organismal metabolic traits, reducing tissue energy reserves (glycogen, lipid, etc.) and altering the expression of metabolic genes (Cazenave et al., 2014; Ings et al., 2012; Melvin, 2016; Smolders et al., 2003; Vidal-Dorsch et al., 2013). However, we still know relatively little about how exposure to WWTP effluent impacts resting and maximal rates of on resting $\mathrm{MO}_{2}$, maximal $\mathrm{MO}_{2}$, and aerobic scope in bluegill, and to examine the changes in liver metabolism that are associated with these impacts. Bluegill and other sunfish species are native across a wide range of North America (Near and Koppelman, 2009) and have been used in several previous ecotoxicological studies (Adams et al., 1992; Du et al., 2018; Porter and Janz, 2003; Theodorakis et al., 1992). Bluegill are an abundant species across southern Ontario in Canada, and can be found across a gradient of exposure near the Dundas WWTP (McCallum et al., 2019). The effluent from this treatment plant flows into Cootes Paradise Marsh, a protected wetland on the western end of Lake Ontario that is an important nature sanctuary and fish breeding ground, but is recognized as a degraded marsh and an International Area of Concern due to historically heavy nutrient and pollution inputs (International Joint Commission, 1999). We have previously shown that resting $\mathrm{MO}_{2}$ was elevated in bluegill that were caged near the Dundas WWTP (Du et al., 2018), but we do not know if wild fish living near the WWTP exhibit similar increases in resting $\mathrm{MO}_{2}$. It is also unknown whether compensatory physiological adjustments can help bluegill increase maximal $\mathrm{MO}_{2}$ and thus maintain aerobic scope. Here, we studied bluegill that were wild-caught in effluent-contaminated waters near the Dundas WWTP, or were caught from clean sites and then caged in effluent-contaminated waters for 4 weeks. We 
1 predicted that we would confirm our previous finding that fish exposed to WWTP effluent would

2 exhibit higher resting $\mathrm{MO}_{2}$ than fish in clean water (Du et al., 2018), and that this metabolic cost

3 of exposure would deplete liver glycogen reserves. Based on the physiological adjustments

4 bluegill make to improve oxygen uptake, transport, and utilization in response to wastewater

5 exposure (Du et al., 2018), we also predicted that fish would compensate by increasing maximal

$6 \quad \mathrm{MO}_{2}$ to help maintain aerobic scope.

\section{Materials and Methods}

\subsection{Collection of wild fish}

Bluegill sunfish were collected by seining and electrofishing from a clean site - Lake

12 Dundas WWTP (Fig. 1). For the latter location, fish were collected $~ 550-830 \mathrm{~m}$ downstream of

13 the Dundas WWTP in Desjardins Canal (between "Site 1" and "Site 2" in Fig. 1C). The Dundas

14 WWTP is a conventional activated sludge treatment facility with nitrification and tertiary sand

15 filtration that treats a daily average of 14.6 million litres of municipal wastewater (City of

16 Hamilton, 2011). Treated effluent is aerated and discharged into the western-most end of the

17 Desjardins Canal (the remnants of a dredged shipping corridor that once connected the former town of Dundas to Hamilton Harbour) and thereby flows into Cootes Paradise Marsh. Fish caught from the clean site in May 2016 were used for the caged exposures described in Section 2.2 ('caged fish'). We also carried out measurements shortly after capture for wild-caught fish

21 from both the clean site (September 2016) and the contaminated site (August and September 2016) ('wild fish'). Most of the fish caught were juveniles (and none were in obvious reproductive condition) and so we did not discern between males and females. Water quality

24 parameters were measured during the daytime photophase on each day of fish collection in Desjardins Canal, including dissolved oxygen and temperature (ProfiLine Oxi 3310 portable oxygen meter; WTW, Weilheim, Germany), total dissolved solids, $\mathrm{pH}$, salinity, conductivity

27 (Multi-Parameter Pocket Testr; Oakton Instruments, Vernon Hills, IL USA). Water quality measurements in Lake Opinicon have been published previously, and the water temperatures in

29 September are generally in a very similar range to those at the other sites during the dates under 30 study - between $18-22^{\circ} \mathrm{C}$ (Agbeti and Smol, 1995; Bremer and Moyes, 2011; Crowder et al., 31 1977). All procedures for collecting wild fish and for subsequent experimental treatments 
1 followed guidelines set out by the Canadian Council on Animal Care and were approved by the

2 McMaster University Animal Research Ethics Board.

\subsection{Caged exposures} University, where they were held in 5001 tanks containing dechlorinated Hamilton tap water with continuous recirculating charcoal filtration, at room temperature $\left(\sim 19^{\circ} \mathrm{C}\right)$ and at a photoperiod of $12 \mathrm{~h}: 12 \mathrm{~h}$ light:dark. Fish were fed four times per week with a mix of beef heart and squid, and tank water was partially changed every week. After remaining in the lab for at least one week, fish were then used in four week caged exposures at one of two sites (Fig. 1C): (i) "Site 2" in Desjardins Canal, 830 m downstream of the Dundas WWTP $\left(43^{\circ} 16^{\prime} 9^{\prime} \mathrm{N}\right.$ 7955'59'W); (ii) Beverly Swamp, the spring-fed headwaters of Cootes Paradise Marsh, which

13 does not receive wastewater inputs $\left(43^{\circ} 21^{\prime} 57^{\prime \prime} \mathrm{N} 80^{\circ} 6^{\prime} 27^{\prime \prime} \mathrm{W}\right)$. We followed similar protocols for 14 caged exposures as we have previously used in the Cootes Paradise Marsh watershed (Du et al., 15 2018; McCallum et al., 2017), except that in the current study we only caged fish at a single 16 contaminated site. This contaminated site used here was at a very similar location to the site we 17 called 'Downstream' in our previous studies (Du et al., 2018; McCallum et al., 2017). We used identical cages to those we used in our previous studies (McCallum et al., 2017), which were made from 1141 plastic totes $(\mathrm{H} 51 \mathrm{~cm} \times \mathrm{W} 81 \mathrm{~cm} \times \mathrm{D} 44.5 \mathrm{~cm})$ drilled with $\sim 200$ holes $(0.5 \mathrm{~cm}$ in diameter) to enable water exchange. We used four replicate cages per site, each containing 14 fish, and we used fish of similar initial sizes in each treatment group. The start date of each exposure was staggered over four weeks, such that one cage of fish from each site was deployed/tested each week from June 1 to July 22, 2016. Every week, we conducted

24 health/survival checks, fed the fish supplementary food (squid cubes), and measured water quality as described above. After the four-week caged exposures, fish were transported back to McMaster University in aerated water from the caging site for subsequent measurements (see 27 below).

We also deployed polar organic chemical integrative samplers (POCIS-HLB; Environmental Sampling Technologies) in association with the caged exposures to quantify 30 concentrations of various pharmaceuticals and personal care products (PPCP) in the water. 31 POCIS were deployed in triplicate from June 21 to July 8 at Beverly Swamp (clean caging site) 
1 and at Desjardins Canal Sites 1 and 2 (contaminated sites). To best represent the conditions

2 experienced by the fish, and to prevent tampering with the samplers in the field, we suspended

3 the POCIS in empty plastic totes with the same specifications as those used to cage fish. POCIS

4 were then retrieved, wrapped in aluminum foil, stored on ice during transport back to McMaster

5 University, and frozen at $-20^{\circ} \mathrm{C}$ for later analysis. A blank POCIS disk was exposed to the air of

6 the field site on the day of retrieval to account for handling and exposure to air-borne

7 contaminants. POCIS extraction and analysis was carried out using equivalent methods to those

8 we have reported previously (McCallum et al., 2017). Time-weighted PPCP concentrations were

9 then derived from known sampling rates for POCIS samplers that have been previously reported

10 in the literature (see McCallum et al., 2017 for details).

\subsection{Respirometry}

We measured resting and maximal rates of oxygen consumption $\left(\mathrm{MO}_{2}\right)$ at $20^{\circ} \mathrm{C}$ using

14 stop-flow respirometry, following well-established protocols that we have previously described

15 for bluegill and for several other species (Borowiec et al., 2016; Borowiec et al., 2015; Borowiec et al., 2018; Crans et al., 2015). $\mathrm{MO}_{2}$ measurements were conducted at McMaster University for

17 all caged fish and for wild fish from contaminated water, and were conducted at the Queen's

18 University Biological Station for wild fish caught in the adjacent Lake Opinicon. The same respirometry system was used at both sites. Measurements at McMaster were conducted in dechlorinated Hamilton tap water maintained at $20^{\circ} \mathrm{C}$. Measurements at the Queen's University Biological Station were conducted in clean sediment-free lake water at $20^{\circ} \mathrm{C}$, which was found to exhibit negligible background $\mathrm{O}_{2}$ flux.

Immediately upon arriving from the field, fish were transferred to respirometry chambers $(675 \mathrm{ml})$ situated in a darkened buffer tank and were continuously flushed with well-oxygenated water (flushing circuit). The chamber was connected to a separate recirculating circuit that flowed past a fibre-optic oxygen sensor (PreSens, Regensburg, Germany). Both circuits were driven by pumps controlled by AutoResp software (Loligo Systems, Tjele, Denmark). Fish were held overnight to allow them time to become accustomed to the chambers. Resting $\mathrm{MO}_{2}$ measurements were conducted the following morning, during two sequential flush and measurement periods. During flush periods $(5 \mathrm{~min})$, both the flush and recirculating pumps were

31 active, such that the chamber received a steady flow of aerated water from the buffer tank. 
1 During measurement periods (5 min), the flush pump was turned off, isolating the chamber from

2 the buffer tank so $\mathrm{MO}_{2}$ could be determined from the rate of change in $\mathrm{O}_{2}$ concentration in the water. We next determined maximal $\mathrm{MO}_{2}$ by measuring peak $\mathrm{O}_{2}$ consumption after exhaustive

4 exercise. The fish was removed from its chamber and transferred to a cylindrical tank (diameter of $29 \mathrm{~cm}$ ) where it was chased to exhaustion (i.e., until the fish would no longer escape from a tail pinch, which generally took $\sim 4$ min or more) and then subjected to one minute of air exposure; this method has been previously shown to elicit higher $\mathrm{MO}_{2}$ than chasing and

8 exhaustion alone (Roche et al., 2013). Fish were quickly returned to the respirometry chamber and $\mathrm{MO}_{2}$ was measured continuously for $12 \mathrm{~h}$, by alternating between flush and measurement periods. Maximal $\mathrm{MO}_{2}$ was the highest $\mathrm{MO}_{2}$ recorded after the fish were returned to the

11 chamber. Absolute aerobic scope was calculated as the difference between maximal and resting

$12 \mathrm{MO}_{2}$, and factorial aerobic scope was calculated as the quotient of maximal and resting $\mathrm{MO}_{2}$.

\subsection{Sampling}

Fish were sampled either immediately upon arrival from the field $(n=5-11$ fish per treatment group) or after completing the respirometry measurements ( $\mathrm{n}=8-10$ per group). Fish

17 were euthanized with a sharp blow to the head followed by pithing, and were quickly weighed.

18 The tail was then severed and blood was collected into heparinized capillary tubes. Haematocrit 19 was measured by spinning tubes for $2.5 \mathrm{~min}$ in a haematocrit centrifuge. The liver was excised, 20 weighed, freeze-clamped, and stored in liquid $\mathrm{N}_{2}$, and then later transferred to $-80^{\circ} \mathrm{C}$ for long21 term storage. The heart and brain were also dissected and weighed.

\subsection{Liver enzyme activities and metabolites}

We measured the maximal activities $\left(\mathrm{V}_{\max }\right)$ of citrate synthase $(\mathrm{CS})$ and cytochrome $\mathrm{c}$ oxidase $(\mathrm{COX})$ in liver tissue from fish sampled after respirometry experiments. Liver tissue was homogenized in a glass tissue grinder in 10 volumes of ice-cold buffer $\left(50 \mathrm{mmol} \mathrm{l}^{-1} \mathrm{KH}_{2} \mathrm{PO}_{4}\right.$,

$270.1 \%$ Triton X-100, $\mathrm{pH} 7.0$ ) and immediately assayed. CS activity was measured as the rate of 28 reduction of DTNB (5,5'-dithiobis-(2-nitrobenzoic acid); detected at $412 \mathrm{~nm}$ with extinction 
coefficient $[\varepsilon]$ of $13.61 \mathrm{mmol}^{-1} \mathrm{~cm}^{-1}$ ), in an assay mixture containing $0.15 \mathrm{mmol} \mathrm{l}^{-1}$ acetyl-coA, $0.15 \mathrm{mmol} \mathrm{l}^{-1} \mathrm{DTNB}, 0.5 \mathrm{mmol} \mathrm{l}^{-1}$ oxaloacetate, and $50 \mathrm{mmol} \mathrm{l}^{-1} \mathrm{KH}_{2} \mathrm{PO}_{4}$ at $\mathrm{pH}$ 8.0. COX activity was measured as the rate of oxidation of reduced cytochrome c (detected at $550 \mathrm{~nm}$ with an $\varepsilon$ of $\left.28.51 \mathrm{mmol}^{-1} \mathrm{~cm}^{-1}\right)$, in an assay buffer containing $0.2 \mathrm{mmol} \mathrm{l}^{-1}$ reduced cytochrome $\mathrm{c}$ and $50 \mathrm{mmol} \mathrm{l}^{-1} \mathrm{KH}_{2} \mathrm{PO}_{4}$ at $\mathrm{pH} 8.0$. Assays were conducted in triplicate at $25^{\circ} \mathrm{C}$ using a SpectraMax Plus 384 microplate reader (Molecular Devices, Sunnyvale, CA, USA) by measuring the rate of change in absorbance for at least $5 \mathrm{~min}$. Enzyme activities were calculated as the reaction rate using all assay components minus the background reaction rate in absence of a key substrate (oxaloacetate or cytochrome c, respectively), and are expressed relative to liver tissue mass.

We measured glycogen content in liver tissue of fish sampled immediately upon arrival from the field. Tissues were homogenized in ice-cold 6\% perchloric acid using a PowerGen 125 homogenizer (Fisher Scientific, Whitby, ON, Canada). We then added $50 \mu \mathrm{l}$ of $1 \mathrm{~mol} \mathrm{l}^{-1} \mathrm{~K}_{2} \mathrm{HCO}_{3}$ and $100 \mu \mathrm{l}$ of $400 \mathrm{mmol} \mathrm{l}^{-1}$ acetate buffer ( $\mathrm{pH} 4.8$ ) to $100 \mu \mathrm{l}$ of homogenate. For half of this

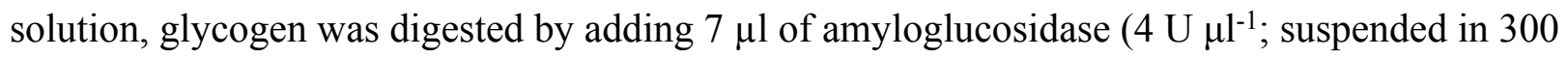
mmol $\mathrm{l}^{-1}$ Tris, $4.05 \mathrm{mmol} \mathrm{l}^{-1} \mathrm{MgSO}_{4}, \mathrm{pH}$ 7.5). The other half of this solution was not digested with amyloglucosidase. All sample homogenates were incubated for $2 \mathrm{~h}$ at $40^{\circ} \mathrm{C}$ and then neutralized with $1 \mathrm{~mol} \mathrm{l}^{-1} \mathrm{~K}_{2} \mathrm{CO}_{3}$. Glucose was then assayed in triplicate in both digested samples (containing both endogenous free glucose and glucose originating from the enzymatic breakdown of glycogen) and undigested samples (containing only endogenous free glucose) by measuring the change in absorbance with the addition of excess of the coupling enzyme hexokinase ( $\left.5 \mathrm{U} \mathrm{ml}^{-1}\right)$ under the following conditions: $1 \mathrm{mmol} \mathrm{l}^{-1} \mathrm{ATP}, 0.5 \mathrm{mmol} \mathrm{l}^{-1} \mathrm{NADP}^{+}, 5$ mmol l-1 $\mathrm{MgCl}_{2}$, and $3 \mathrm{U} \mathrm{ml}^{-1}$ glucose-6-phosphate dehydrogenase in $20 \mathrm{mmol} \mathrm{l}^{-1}$ imidazole buffer ( $\mathrm{pH}$ 7.4). The difference in glucose content detected between the digested and undigested samples was used to calculate glycogen content, and is expressed relative to liver tissue mass.

To evaluate the potential influence of variation in liver size, we also calculated the total liver enzyme activities and glycogen content for the entire fish. This was accomplished by multiplying the enzyme activities and glycogen content in units per g tissue by the mass of the liver in grams. These data are expressed here relative to fish body mass (e.g., liver CS activity per $g$ fish mass). 


\subsection{Statistics}

All data were analyzed using R version 3.3 (R Core Team, 2016). Survival was analysed using a generalized linear mixed model (package glmer) with cage and experimental week set as random effects and caging site and exposure week set as fixed effects. Other data were analyzed with a linear regression model using exposure (clean or contaminated environment) and caging (caged or wild) as fixed independent variables (interaction terms were tested and were not significant). Body mass was included as an additional fixed independent variable, with the exception of body mass itself and the enzyme and metabolite data expressed per $\mathrm{g}$ fish mass. Each test was initially run including the potential interactions between the fixed factors. In all cases except for brain mass, the interactions did not approach significance $(P \geq 0.1)$ and were removed from the final models reported here. For statistical analyses of the $\mathrm{MO}_{2}$ data, we used the absolute values in units $\mathrm{mmol}_{2} \mathrm{~h}^{-1}$ and included body mass as a fixed independent variable, but we report the data normalized to body mass in units of $\mathrm{mmol} \mathrm{O}_{2} \mathrm{~h}^{-1} \mathrm{~kg}^{-1}$ to facilitate comparison with the literature. $\mathrm{P}<0.05$ is considered significant throughout. We report effect sizes using eta-squared $\left(\eta^{2}\right.$; sjstats package).

\section{Results}

\subsection{Water quality and PPCP concentrations}

There were differences in water quality and PPCP concentrations between clean and contaminated sites. Most of the water quality parameters measured (all except $\mathrm{pH}$ ) were higher at contaminated sites than at the clean site (Table 1). As expected, water temperature tended to increase over the period of caging from June to July, from $\sim 15^{\circ} \mathrm{C}$ to $\sim 22^{\circ} \mathrm{C}$ at the clean caging site and from $\sim 20^{\circ} \mathrm{C}$ to $\sim 25^{\circ} \mathrm{C}$ at contaminated site 2 . At the clean caging site, this warming was associated with a modest drop in dissolved $\mathrm{O}_{2}$ (from $\sim 7$ to $\sim 6 \mathrm{mg} \mathrm{l}^{-1}$ ) likely due to the reduction in $\mathrm{O}_{2}$ solubility at warmer temperatures. At contaminated site 2, however, dissolved $\mathrm{O}_{2}$ tended to rise from June to July (from $\sim 7$ to $\sim 13 \mathrm{mg} \mathrm{l}^{-1}$ ), potentially because of effects of temperature on photosynthetic activity or from changes in the oxygenation of effluent leaving the WWTP. Indeed, average dissolved $\mathrm{O}_{2}$ at both contaminated sites (Table 1) exceeded that expected for airsaturated water at the temperatures measured (Boutilier et al., 1984), suggested that the water was super-saturated during the daytime photophase when the measurements were obtained. Of the 24 pharmaceuticals, pharmaceutical metabolites, and personal care products that we 
1 measured in the water, 18 were detected at the contaminated sites (Table 2). This included food 2 products, several anti-depressants and their metabolites, several beta-blockers, and various other PPCPs. Only 2 compounds were detected at the control site (sucralose and the lipid regulator gemfibrozil), but concentrations were lower than at the contaminated sites.

\subsection{Survival}

Fish that were cage-exposed to the site contaminated by wastewater effluent had reduced survival (Fig. 2). Mortality was low ( $\sim 5 \%)$ over the first 3 weeks of caging at the clean site, but appeared to increase modestly between the third and fourth weeks. Fish that were caged at the site contaminated by wastewater effluent had higher mortality, such that survival was only $57 \%$

$11 \pm 12 \%($ mean $\pm \mathrm{SE})$ after 4 weeks of exposure.

\subsection{Metabolism}

Resting rates of metabolism, as reflected by whole-animal $\mathrm{O}_{2}$ consumption rates $\left(\mathrm{MO}_{2}\right)$, were increased in fish from the site contaminated by wastewater effluent (Fig. 3A). There was a statistically significant effect of site on resting $\mathrm{MO}_{2}$, and although the effect of caging was not significant, the increase in resting $\mathrm{MO}_{2}$ at the contaminated site appeared to be greater among wild-caught individuals ( $\sim 50 \%$ ), who were caught between Site 1 and Site 2 in Desjardins Canal

19 (Fig. 1), than among caged individuals ( 30\%), who were caged at Site 2 in the canal. There was 20 an effect of body mass on resting $\mathrm{MO}_{2}$, as expected, but there were no significant differences in 21 body mass between treatment groups (Fig. 4).

There were no appreciable effects of wastewater exposure on maximal $\mathrm{MO}_{2}$ (Fig. 3B). Maximal $\mathrm{MO}_{2}$ was determined by measuring the highest $\mathrm{MO}_{2}$ achieved after an exhaustive chase, and was found to elicit similarly high $\mathrm{MO}_{2}$ to the maximal rates we have measured in this species during sustained swimming (Crans et al., 2015). Although there were no statistically significant effects of site or caging on maximal $\mathrm{MO}_{2}$, there appeared to be some modest nonsignificant variation across groups that resembled the variation in resting $\mathrm{MO}_{2}$. As a result, there were no significant effects of site or caging on absolute (difference between maximal and resting $\mathrm{MO}_{2}$ ) or factorial (quotient of maximal and resting $\mathrm{MO}_{2}$ ) aerobic scopes (Fig. 3C,D). 
Organ sizes were altered in fish from the site contaminated by wastewater effluent (Fig. 4). There were no statistically significant effects of site or caging on body mass, but relative brain mass was $\sim 50 \%$ smaller in wild-caught (but not caged) fish from the contaminated site. Relative liver mass was $\sim 30-35 \%$ larger and relative heart mass was $\sim 30-38 \%$ larger in both wild-caught and caged fish from the contaminated site, and there were no significant effects of caging on these traits. Haematocrit was lower overall in caged fish than in wild fish, but there were no differences between fish from the clean and contaminated sites (Table 3).

The activities of cytochrome c oxidase (COX; complex IV of the mitochondrial electron transport system) and citrate synthase (CS; an enzyme in the tricarboxylic acid cycle) per gram of liver tissue (i.e., specific enzyme activities) were similar across groups, as reflected by the lack of any statistically significant effects of site or caging on these traits (Fig. 5A,C). However, there was a significant effect of exposure site (but not caging) on liver activities of COX and CS per gram of fish (i.e., product of activity per liver mass and liver mass per body mass) (Fig. $5 B, D)$. These results suggest that the increase in liver size led to a comparable increase in the cumulative mitochondrial oxidative capacity of the liver in fish from the contaminated site.

Glycogen content per gram of liver tissue (i.e., specific glycogen content) was lower in fish exposed to wastewater effluent, as indicated by the significant effects of exposure site (but not caging) on this variable (Fig. 6A). This reduction in specific glycogen content was offset by the differences in liver mass, such that there was no significant effect of site or caging on the liver glycogen content per gram of fish (Fig. 6B). Nevertheless, even though the liver increased in size, liver cells may have partially depleted glycogen reserves in fish from the contaminated site.

\section{Discussion} a common species that is native to North America, the bluegill sunfish. Exposure increased resting $\mathrm{MO}_{2}$ and appeared to result in energy stress, as reflected by reductions in the specific glycogen content of the liver, and reduced survival in fish that were caged in effluentcontaminated water. However, physiological compensations appeared to help offset some of the 
1 detrimental impacts in fish that survived exposure. The metabolic cost of exposure did not reduce aerobic scope due to subtle (though non-significant) changes in maximal $\mathrm{MO}_{2}$. Exposed fish also had larger heart and liver masses. The increase in liver size increased the cumulative mitochondrial oxidative-capacity of this organ in the fish, and helped offset the reduction in specific glycogen content. Nevertheless, the observed mortality and the considerable reduction in bluegill abundance in the most contaminated areas close to the WWTP (McCallum et al., 2019) suggest that this species may not be capable of fully compensating for the detrimental impacts of exposure.

\subsection{Metabolic costs of wastewater exposure}

Bluegill exposed to WWTP effluent had higher resting metabolic rates than fish from clean sites, and this pattern was particularly evident in fish that were wild caught at contaminated sites (Fig. 3A). This suggests that the wild fish experienced a metabolic cost of wastewater exposure, as we observed in a previous study of bluegill caged near the same WWTP (Du et al., 2018). It is possible that wild fish move throughout the gradient of exposure from the area of the WWTP outfall into the cleaner waters in Cootes Paradise Marsh, and this movement could have modulated the impacts of WWTP effluent. However, the fish clearly did not move away sufficiently often to eliminate the metabolic costs of exposure. Our results therefore contribute to the growing evidence that resting metabolism can be increased by chronic exposure to a range of chemical contaminants, including WWTP effluent (Du et al., 2018; Mehdi et al., 2018), crude oil (Pasparakis et al., 2016), organochloride pesticide (dieldrin) (Beyers et al., 1999), and some metals (Al) (Wilson et al., 1994).

Metabolic costs of wastewater exposure could reduce health and fitness by increasing food demands. In theory, if fish do not adjust to higher metabolic demands by increasing food consumption, then growth and investment in reproduction could be impaired. In fact, food consumption is often reduced during exposure to toxicants, and combined effects of increased metabolic rate and reduced food consumption may explain why fish often lose body mass during exposure to contaminants (Beyers et al., 1999; Mennigen et al., 2010). Although body size was similar across treatments in the current study, bluegill exposed to WWTP effluent had lower specific glycogen content in the liver (Fig. 6A), as previously observed in caged exposures of rainbow trout to treated WWTP effluent (Ings et al., 2012) and of a characin species 
1 (Prochilodus lineatus) to untreated sewage effluent (Cazenave et al., 2014). The changes we observed here were not major and still left exposed fish with more than half of specific glycogen reserves of control fish, but they could suggest that energy storage is restricted by exposure to wastewater effluent, which could impair resource investment into growth and reproduction (Fig. 2). example, juvenile zebrafish that were previously exposed as embryos to the wastewater produced from hydraulic fracturing exhibited reduced maximal $\mathrm{MO}_{2}$, thus reducing aerobic scope and swimming performance (Folkerts et al., 2017). Toxicant exposure can also impair locomotory performance by increasing the metabolic cost of transport, as observed in juvenile rainbow trout exposed to waterborne copper (McGeer et al., 2000). However, our results suggest that exposure to wastewater effluent (at least that from the Dundas WWTP) does not reduce aerobic scope in bluegill, due to compensatory physiological adjustments to improve respiratory $\mathrm{O}_{2}$ transport. There appeared to be subtle (though non-significant) variation in maximal $\mathrm{MO}_{2}$ that exhibited a similar pattern to the variation in resting $\mathrm{MO}_{2}$ (Fig. 3A,B), such that aerobic scope was maintained across treatments (Fig. 3C,D). Fish exposed to WWTP effluent also had larger hearts (Fig. 4), which may have increased the capacity for circulating blood to support the metabolism support routine activities. higher water temperatures at our contaminated sites. $\mathrm{MO}_{2}$ measurements were made at a common intermediate temperature of $20^{\circ} \mathrm{C}$ (within $3^{\circ} \mathrm{C}$ of the average temperatures across all sites; Table 1), so the immediate kinetic effects of temperature on reaction rates cannot account for the observed differences between groups. Thermal history during may have impacted $\mathrm{MO}_{2}$, but acclimation to warmer temperatures tends to reduce $\mathrm{MO}_{2}$ when compared at a common 
temperature (Schaefer and Walters, 2010; White et al., 2012). If such an effect of thermal

2 acclimation were to have occurred in bluegill, it would have reduced rather than accentuated the apparent increases in $\mathrm{MO}_{2}$ in fish from contaminated sites. However, the warmer temperatures at contaminated sites may have increased routine activity and energy expenditure in the field (Kent and Ojanguren, 2015), which could have accentuated any potential energy deficits that arose as a result of wastewater exposure, and thus affected survival and/or the potential metabolic signals driving changes in whole-body and tissue metabolism. Other water quality differences at contaminated sites are not anticipated to have been large enough (i.e., dissolved solids, conductivity, and salinity) or in the right direction (i.e., dissolved $\mathrm{O}_{2}$ ) to cause chronic disruption of metabolic rate.

\subsection{Wastewater exposure expands liver size and mitochondrial oxidative capacity}

Exposure to WWTP effluent appears to increase the capacity for energy metabolism in the liver. In the current study, we show that bluegill exposed to effluent from the Dundas WWTP had larger livers (Fig. 4C) with a preservation of the specific activity of mitochondrial enzymes (cytochrome c oxidase, citrate synthase), such that there was an increase in the cumulative oxidative capacity of this organ in the fish (Fig. 5). We have previously shown that bluegill exposed to effluent from the Dundas WWTP also exhibit improvements in the function of liver mitochondria, including increases in the capacity for oxidative phosphorylation and decreases in the emission of reactive oxygen species (Du et al., 2018). Exposure to some other contaminants has also been shown to increase COX or CS activity in the liver (Gagnon, 2002; Pandelides et al., 2014), suggesting that increases in the mitochondrial oxidative capacity of this organ may be a common response of fish to some forms of aquatic pollution.

The ultimate cause of adjustments in liver size and mitochondrial oxidative capacity are currently unclear. One possible explanation is that they are induced by cellular energy limitation and help support the general energy demands of detoxification; the liver is the main site of detoxification for many xenobiotics (Burkina et al., 2015), and toxicant exposure has in some cases been shown to induce concurrent increases in the activities of cytochrome c oxidase and phase I detoxification enzymes (ethoxyresorufin- $O$-deethylase, EROD) in the liver (Gagnon,

30 2002). Another possibility is that WWTP effluent contains compounds that disrupt metabolism 31 directly, thus altering liver and whole-body metabolism. For example, several of the compounds 
1 measured at the contaminated sites target metabolic or cardiorespiratory processes (e.g., lipid regulators, beta-blockers, etc.), and WWTP effluent is known to contain substances that interact with nuclear receptors regulating metabolism (e.g., pregnane $\mathrm{X}$ receptor, thyroid hormone receptor) (Hakkola et al., 2016; Mughal et al., 2018). These possibilities are not mutually exclusive and could all contribute to increasing the oxidative capacity of the liver during exposure to WWTP effluent.

\subsection{Effects of caging} in fish caged at the clean site was low for the first 3 weeks but did increase thereafter, reflecting

11 a potential detrimental effect of prolonged caging (Fig. 2). Caged fish also had lower haematocrit 12 than wild fish, but haematocrit was still relatively high across all groups, and the higher levels in 13 wild fish could have resulted from exposure to a more variable environment throughout the 14 gradient of exposure from the WWTP (Table 3). Otherwise, many of the effects of exposure appeared to be greater in the wild fish than the caged fish (resting and maximal $\mathrm{MO}_{2}$, liver COX activity), which could have resulted from the differences in activity, stress, duration of exposure,

17 food consumption, or a range of other factors that likely differed between wild and caged fish.

18 Nevertheless, fish caging studies are an extremely valuable technique in aquatic toxicology that 19 provides more experimental control than studies of wild animals in contaminated environments

20 (Oikari, 2006). There are advantages and disadvantages to studying fish in wild or in caged 21 conditions, and our approach of studying the effects of exposure in both conditions allows us to overcome the disadvantages of either approach in isolation. The emergent conclusion from doing so is that exposure to WWTP effluent can have a significant metabolic cost to fish. Our findings add to the growing body of evidence that various forms of pollution can have significant metabolic implications that may affect health and fitness in the wild.

\section{Acknowledgements}

28 The authors would like to thank Brett Culbert, Oliver Wearing, Catie Ivy, Grant McClelland, 29 Ryan Lau, Michael Lawrence, Aaron Zoldero, Sulayman Lyons, Jennifer Bowman, Kyle 30 Mataya, Tys Theysmeyer, Bert Posedowski, and Mark Bainbridge for their exceptional help and assistance, as well as three anonymous referees for helpful comments on an earlier version of this 
manuscript. We are also grateful to Jim Sherry and Jason Miller from Environment and Climate Change Canada for lending us exposure cages, and to Miro Cika for assistance with building cages. This research was supported by funding to S.B. and G.R.S. from the Royal Bank of Canada (RBC) Blue Water Initiative (made possible by a generous gift from the RBC Foundation), as well as a Natural Sciences and Engineering Research Council of Canada (NSERC) Engage Plus Grant to G.R.S. S.N.N.D. was supported by an Ontario Graduate Scholarship, E.S.M. and B.G.B. were supported by NSERC Post-Graduate Scholarships, and

\section{References}

Adams, S.M., Crumby, W.D., Greeley, M.S., Ryon, M.G., Schilling, E.M., 1992. Relationships between physiological and fish population responses in a contaminated stream. Environ. Toxicol. Chem. 11, 1549-1557.

Agbeti, M.D., Smol, J.P., 1995. Winter limnology: a comparison of physical, chemical and biological characteristics in two temperate lakes during ice cover. Hydrobiologia 304, 221-234.

Beyers, D.W., Rice, J.A., Clements, W.H., Henry, C.J., 1999. Estimating physiological cost of chemical exposure: integrating energetics and stress to quantify toxic effects in fish. Can. J. Fish. Aquat. Sci. 56, 814-822.

Bjerselius, R., Lundstedt-Enkel, K., Olsen, H., Mayer, I., Dimberg, K., 2001. Male goldfish reproductive behaviour and physiology are severely affected by exogenous exposure to 17ß-estradiol. Aquat. Toxicol. 53, 139-152.

Borowiec, B.G., Crans, K.D., Khajali, F., Pranckevicius, N.A., Young, A., Scott, G.R., 2016. Interspecific and environment-induced variation in hypoxia tolerance in sunfish. Comp. Biochem. Physiol. A 198, 59-71.

Borowiec, B.G., Darcy, K.L., Gillette, D.M., Scott, G.R., 2015. Distinct physiological strategies are used to cope with constant hypoxia and intermittent hypoxia in killifish (Fundulus heteroclitus). J. Exp. Biol. 218, 1198-1211.

Borowiec, B.G., O’Connor, C.M., Goodick, K., Scott, G.R., Balshine, S., 2018. The preference for social affiliation renders fish willing to accept lower $\mathrm{O}_{2}$ levels. Physiol. Biochem. Zool. 91, 716-724. 
1 Boutilier, R.G., Heming, T.A., Iwama, G.K., 1984. Physicochemical parameters for use in fish respiratory physiology, in: W.S. Hoar, D.J. Randall (Eds.), Fish Physiol. Academic Press, London, UK, 403-430.

Bremer, K., Moyes, C.D., 2011. Origins of variation in muscle cytochrome c oxidase activity within and between fish species. J. Exp. Biol. 214, 1888-1895.

Brooks, B.W., Riley, T.M., Taylor, R.D., 2006. Water quality of effluent-dominated ecosystems: ecotoxicological, hydrological, and management considerations. Hydrobiologia 556, 365379.

Burkina, V., Zlabek, V., Zamaratskaia, G., 2015. Effects of pharmaceuticals present in aquatic environment on Phase I metabolism in fish. Environ. Toxicol. Pharmacol. 40, 430-444.

Callaghan, N.I., MacCormack, T.J., 2017. Ecophysiological perspectives on engineered nanomaterial toxicity in fish and crustaceans. Comp. Biochem. Physiol. C Toxicol. Pharmacol. 193, 30-41.

Cazenave, J., Bacchetta, C., Rossi, A., Ale, A., Campana, M., Parma, M.J., 2014. Deleterious effects of wastewater on the health status of fish: A field caging study. Ecol. Indicators 38, 104-112.

City of Hamilton, 2011. City of Hamilton Wastewater Treatment Facilities 2011 Annual Report. http://www2.hamilton.ca/.

Claireaux, G., Lefrancois, C., 2007. Linking environmental variability and fish performance: integration through the concept of scope for activity. Philosophical Transactions of the Royal Society B-Biological Sciences 362, 2031-2041.

Craig, P.M., Wood, C.M., McClelland, G.B., 2010. Water chemistry alters gene expression and physiological end points of chronic waterborne copper exposure in zebrafish, Danio rerio. Environ. Sci. Technol. 44, 2156-2162.

Crans, K.D., Pranckevicius, N.A., Scott, G.R., 2015. Physiological tradeoffs may underlie the evolution of hypoxia tolerance and exercise performance in sunfish (Centrarchidae). J. Exp. Biol. 218, 3264-3275.

Crowder, A.A., Bristow, J.M., King, M.R., Vanderkloet, S., 1977. Distribution, seasonality, and biomass of aquatic macrophytes in Lake Opinicon (Eastern Ontario). Nat. Can. 104, 441456. 
1 Du, S.N.N., McCallum, E.S., Vaseghi-Shanjani, M., Choi, J.A., Warriner, T.R., Balshine, S., Scott, G.R., 2018. Metabolic costs of exposure to wastewater effluent lead to compensatory adjustments in respiratory physiology in bluegill sunfish. Environ. Sci. Technol. 52, 801-811.

Eliason, E.J., Farrell, A.P., 2016. Oxygen uptake in Pacific salmon Oncorhynchus spp.: when ecology and physiology meet. J. Fish Biol. 88, 359-388.

Folkerts, E.J., Blewett, T.A., He, Y., Goss, G.G., 2017. Alterations to juvenile zebrafish (Danio rerio) swim performance after acute embryonic exposure to sub-lethal exposures of hydraulic fracturing flowback and produced water. Aquat. Toxicol. 193, 50-59.

Gagnon, M.M., 2002. Metabolic disturbances in fish exposed to sodium pentachlorophenate (NaPCP) and 3,3',4,4',5-pentachlorobiphenyl (PCB126), individually or combined. Comp. Biochem. Physiol. C Toxicol. Pharmacol. 132, 425-435.

Gros, M., Petrovic, M., Ginebreda, A., Barcelo, D., 2010. Removal of pharmaceuticals during wastewater treatment and environmental risk assessment using hazard indexes. Environ. Int. 36, 15-26.

Hahn, M.E., 2011. Mechanistic research in aquatic toxicology: perspectives and future directions. Aquat. Toxicol. 105, 67-71.

Hakkola, J., Rysa, J., Hukkanen, J., 2016. Regulation of hepatic energy metabolism by the nuclear receptor PXR. Biochim. Biophys. Acta 1859, 1072-1082.

Ings, J.S., Oakes, K.D., Vijayan, M.M., Servos, M.R., 2012. Temporal changes in stress and tissue-specific metabolic responses to municipal wastewater effluent exposure in rainbow trout. Comparative Biochemistry and Physiology C-Toxicology \& Pharmacology 156, $67-74$.

International Joint Commission, 1999. Hamilton Harbour: Area of Concern Status Assessment. ISBN 1-894280-12-1. http://ijc.org/php/publications/html/hamhar/hamharsa.html.

Kent, M., Ojanguren, A.F., 2015. The effect of water temperature on routine swimming behaviour of new born guppies (Poecilia reticulata). Biology Open, BIO20149829.

Kolpin, D.W., Furlong, E.T., Meyer, M.T., Thurman, E.M., Zaugg, S.D., Barber, L.B., Buxton, H.T., 2002. Pharmaceuticals, hormones, and other organic wastewater contaminants in US streams, 1999-2000: A national reconnaissance. Environ. Sci. Technol. 36, 12021211. 
1 Little, E.E., Finger, S.E., 1990. Swimming behavior as an indicator of sublethal toxicity in fish.

2 Environ. Toxicol. Chem. 9, 13-19.

3 Marcogliese, D.J., Blaise, C., Cyr, D., de Lafontaine, Y., Fournier, M., Gagne, F., Gagnon, C.,

4 Hudon, C., 2015. Effects of a major municipal effluent on the St. Lawrence River: A case 5 study. Ambio 44, 257-274.

6 McCallum, E.S., Du, S.N.N., Vaseghi-Shanjani, M., Choi, J.A., Warriner, T.R., Sultana, T., 7 Scott, G.R., Balshine, S., 2017. In situ exposure to wastewater effluent reduces survival 8 but has little effect on the behaviour or physiology of an invasive Great Lakes fish. $9 \quad$ Aquat. Toxicol. 184, 37-48.

McCallum, E.S., Nikel, K.E., Mehdi, H., Du, S.N.N., Bowman, J.E., Midwood, J.D., Kidd, K.A., Scott, G.R., Balshine, S., 2019. Municipal wastewater effluent affects fish communities: a multi-year study involving two wastewater treatment plants. Environ. Pollut. Revision requested.

McGeer, J.C., Szebedinszky, C., McDonald, D.G., Wood, C.M., 2000. Effects of chronic sublethal exposure to waterborne $\mathrm{Cu}, \mathrm{Cd}$ or $\mathrm{Zn}$ in rainbow trout. 1: Iono-regulatory disturbance and metabolic costs. Aquat. Toxicol. 50, 231-243.

Mehdi, H., Dickson, F.H., Bragg, L.M., Servos, M.R., Craig, P.M., 2018. Impacts of wastewater treatment plant effluent on energetics and stress response of rainbow darter (Etheostoma caeruleum) in the Grand River watershed. Comp. Biochem. Physiol. B Biochem. Mol. Biol. 224, 270-279.

Melvin, S.D., 2016. Short-term exposure to municipal wastewater influences energy, growth, and swimming performance in juvenile Empire Gudgeons (Hypseleotris compressa). Aquat. Toxicol. 170, 271-278.

Mennigen, J.A., Sassine, J., Trudeau, V.L., Moon, T.W., 2010. Waterborne fluoxetine disrupts feeding and energy metabolism in the goldfish Carassius auratus. Aquat. Toxicol. 100, 128-137.

Metcalfe, N.B., Van Leeuwen, T.E., Killen, S.S., 2016. Does individual variation in metabolic phenotype predict fish behaviour and performance? J. Fish Biol. 88, 298-321.

Mothersill, C., Mosse, I., Seymour, C., 2007. Multiple stressors: a challenge for the future, NATO Science for Peace and Security Series C: Environmental Security. Springer, Heidelberg. 
1 Mughal, B.B., Fini, J.B., Demeneix, B.A., 2018. Thyroid-disrupting chemicals and brain development: an update. Endocrine Connections 7, R160-R186.

Nash, J.P., Kime, D.E., Van der Ven, L.T.M., Wester, P.W., Brion, F., Maack, G., StahlschmidtAllner, P., Tyler, C.R., 2004. Long-term exposure to environmental concentrations of the pharmaceutical ethynylestradiol causes reproductive failure in fish. Environ. Health Perspect. 112, 1725-1733.

Near, T.J., Koppelman, J.B., 2009. Species diversity, phylogeny and phylogeography of Centrarchidae, in: S.J. Cooke, D.P. Philipp (Eds.), Centrarchid Fishes: Diversity, Biology, And Conservation. Blackwell Science, 1-38.

Nikolaou, A., Meric, S., Fatta, D., 2007. Occurrence patterns of pharmaceuticals in water and wastewater environments. Anal. Bioanal. Chem. 387, 1225-1234.

Noyes, P.D., McElwee, M.K., Miller, H.D., Clark, B.W., Van Tiem, L.A., Walcott, K.C., Erwin, K.N., Levin, E.D., 2009. The toxicology of climate change: environmental contaminants in a warming world. Environ. Int. 35, 971-986.

Oikari, A., 2006. Caging techniques for field exposures of fish to chemical contaminants. Aquat. Toxicol. 78, 370-381.

Pandelides, Z., Guchardi, J., Holdway, D., 2014. Dehydroabietic acid (DHAA) alters metabolic enzyme activity and the effects of $17 \beta$-estradiol in rainbow trout (Oncorhynchus mykiss). Ecotoxicol. Environ. Saf. 101, 168-176.

Parrott, J.L., Blunt, B.R., 2005. Life-cycle exposure of fathead minnows (Pimephales promelas) to an ethinylestradiol concentration below $1 \mathrm{ng} / \mathrm{L}$ reduces egg fertilization success and demasculinizes males. EnTox 20, 131-141.

Pasparakis, C., Mager, E.M., Stieglitz, J.D., Benetti, D., Grosell, M., 2016. Effects of Deepwater Horizon crude oil exposure, temperature and developmental stage on oxygen consumption of embryonic and larval mahi-mahi (Coryphaena hippurus). Aquat. Toxicol. 181, 113-123.

Plaut, I., 2001. Critical swimming speed: its ecological relevance. Comp. Biochem. Physiol. A. 131, 41-50.

Porter, C.M., Janz, D.M., 2003. Treated municipal sewage discharge affects multiple levels of biological organization in fish. Ecotoxicol. Environ. Saf. 54, 199-206. 
1 R Core Team, 2016. R: A language and environment for statistical computing, R Foundation for Statistical Computing (http://www.R-project.org/), Vienna, Austria.

Roche, D.G., Binning, S.A., Bosiger, Y., Johansen, J.L., Rummer, J.L., 2013. Finding the best estimates of metabolic rates in a coral reef fish. J. Exp. Biol. 216, 2103-2110.

Schaefer, J., Walters, A., 2010. Metabolic cold adaptation and developmental plasticity in metabolic rates among species in the Fundulus notatus species complex. Funct. Ecol. 24, 1087-1094.

Schultz, M.M., Furlong, E.T., Kolpin, D.W., Werner, S.L., Schoenfuss, H.L., Barber, L.B., Blazer, V.S., Norris, D.O., Vajda, A.M., 2010. Antidepressant pharmaceuticals in two US effluent-impacted streams: occurrence and fate in water and sediment, and selective uptake in fish neural tissue. Environ. Sci. Technol. 44, 1918-1925.

Scott, G.R., Sloman, K.A., 2004. The effects of environmental pollutants on complex fish behaviour: integrating behavioural and physiological indicators of toxicity. Aquat. Toxicol. 68, 369-392.

Smolders, R., De Boeck, G., Blust, R., 2003. Changes in cellular energy budget as a measure of whole effluent toxicity in zebrafish (Danio rerio). Environ. Toxicol. Chem. 22, 890-899.

Theodorakis, C.W., D'Surney, S.J., Bickham, J.W., Lyne, T.B., Bradley, B.P., Hawkins, W.E., Farkas, W.L., McCarthy, J.F., Shugart, L.R., 1992. Sequential expression of biomarkers in bluegill sunfish exposed to contaminated sediment. Ecotoxicology 1, 45-73.

Vidal-Dorsch, D.E., Colli-Dula, R.C., Bay, S.M., Greenstein, D.J., Wiborg, L., Petschauer, D., Denslow, N.D., 2013. Gene expression of fathead minnows (Pimephales promelas) exposed to two types of treated municipal wastewater effluents. Environ. Sci. Technol. 47, 11268-11277.

White, C.R., Alton, L.A., Frappell, P.B., 2012. Metabolic cold adaptation in fishes occurs at the level of whole animal, mitochondria and enzyme. Proc. R. Soc. B. 279, 1740-1747.

Wilson, R.W., Bergman, H.L., Wood, C.M., 1994. Metabolic costs and physiological consequences of acclimation to aluminum in juvenile rainbow trout (Oncorhynchus mykiss). 2: Gill morphology, swimming performance, and aerobic scope. Can. J. Fish. Aquat. Sci. 51, 536-544. 


\section{Table 1}

Water quality parameters. Beverly Swamp and Desjardins Canal Site 2 were monitored weekly over 8 weeks (June 1 - July 22, 2016). Desjardins Canal Site 1 was measured on days of fish collection (August 18 and September 22, 2016). Data are shown as means \pm SE. All parameters except $\mathrm{pH}$ were significantly different between Beverley Swamp and Desjardins Canal Site 2 $(\mathrm{P}<0.05)$.

\begin{tabular}{lccc}
\hline & Clean Site & \multicolumn{2}{c}{ Contaminated Sites } \\
& $\begin{array}{c}\text { Beverly } \\
\text { Swamp }\end{array}$ & $\begin{array}{c}\text { Desjardins } \\
\text { Canal Site 1 }\end{array}$ & $\begin{array}{c}\text { Desjardins } \\
\text { Canal Site 2 }\end{array}$ \\
\hline Temperature $\left({ }^{\circ} \mathrm{C}\right)$ & $17.4 \pm 1.2$ & $22.9 \pm 1.4$ & $22.6 \pm 0.8$ \\
Dissolved $\mathrm{O}_{2}\left(\mathrm{mg} \mathrm{l}^{-1}\right)$ & $6.63 \pm 0.21$ & $9.41 \pm 0.15$ & $11.9 \pm 1.8$ \\
$\mathrm{pH}$ & $8.16 \pm 0.15$ & $8.01 \pm 0.37$ & $7.97 \pm 0.27$ \\
Total dissolved solids $(\mathrm{ppm})$ & $542 \pm 11$ & $698 \pm 33$ & $816 \pm 19$ \\
Conductivity $(\mu \mathrm{S})$ & $765 \pm 15$ & $980 \pm 46$ & $1140 \pm 27$ \\
Salinity $(\mathrm{ppm})$ & $369 \pm 8$ & $485 \pm 26$ & $569 \pm 13$ \\
\hline
\end{tabular}




\section{Table 2}

Time-weighted concentrations (ng/l) of pharmaceutical and personal care product (PPCP) compounds detected at each site using POCIS samplers (the average values of 3 technical replicates per site are shown). ND, not detected.

\begin{tabular}{|c|c|c|c|c|}
\hline \multirow[b]{2}{*}{ Compound } & \multirow[b]{2}{*}{ Class } & \multirow{2}{*}{$\begin{array}{c}\frac{\text { Clean Site }}{\text { Beverley }} \\
\text { Swamp }\end{array}$} & \multicolumn{2}{|c|}{ Contaminated Sites } \\
\hline & & & $\begin{array}{c}\text { Desjardins } \\
\text { Canal Site } 1\end{array}$ & $\begin{array}{c}\text { Desjardins } \\
\text { Canal Site } 2\end{array}$ \\
\hline Caffeine & food & ND & 428.4 & 149.2 \\
\hline Sucralose & food & 10.24 & 2580.6 & 1226.4 \\
\hline Carbamazepine & anti-seizure & ND & 116.6 & 59.8 \\
\hline Venlafaxine & antidepressant & ND & 38.7 & 33.4 \\
\hline$O$-dm-venlafaxine & metabolite & ND & 4.8 & 3.4 \\
\hline$N$-dm-venlafaxine & metabolite & ND & 12.4 & 9.5 \\
\hline Sertraline & antidepressant & ND & 6.4 & 8.0 \\
\hline dm-sertraline & metabolite & ND & 18.6 & 15.3 \\
\hline Citalopram & antidepressant & ND & 0.5 & 0.5 \\
\hline Fluoxetine & antidepressant & ND & 0.05 & 0.03 \\
\hline Atenolol & beta-blocker & ND & 6.2 & 3.3 \\
\hline Metoprolol & beta-blocker & ND & 5.8 & 4.3 \\
\hline Propanolol & beta-blocker & ND & 25.0 & 20.9 \\
\hline Gemfibrozil & lipid regulator & 0.3 & 1.3 & 0.9 \\
\hline Acetaminophen & analgesic & ND & 9.8 & 11.9 \\
\hline Ibuprofen & anti-inflammatory & ND & 51.6 & 5.1 \\
\hline Naproxen & anti-inflammatory & ND & ND & ND \\
\hline Trimethoprim & anti-biotic & ND & ND & ND \\
\hline Sulfamethoxazole & anti-biotic & ND & ND & ND \\
\hline Triclosan & antibacterial & ND & ND & ND \\
\hline Estrone (E1) & hormone & ND & ND & ND \\
\hline Estradiol (E2) & hormone & ND & ND & ND \\
\hline Androstenedione & hormone & ND & 0.08 & 0.05 \\
\hline Testosterone & hormone & ND & ND & 0.3 \\
\hline
\end{tabular}




\section{Table 3}

Haematocrit (\%) was reduced by caging, but was unaffected by exposure to wastewater effluent. Data are shown as means $\pm \mathrm{SE}(\mathrm{N})$.

\begin{tabular}{lcc}
\hline & Clean site & Contaminated site \\
\hline Wild-caught fish & $40.3 \pm 2.6(18)$ & $39.2 \pm 2.4(12)$ \\
Caged fish & $31.0 \pm 1.4(14)$ & $30.2 \pm 3.6(10)$ \\
& \\
Fixed effect of wastewater exposure: $\mathrm{F}=0.272, \eta^{2}=0.004, \mathrm{P}=0.604$ & \\
Fixed effect of caging: $\mathrm{F}=14.39, \eta^{2}=0.222, \mathrm{P}=0.0004$ & \\
Effect of body mass: $\mathrm{F}=0.059, \eta^{2}=0.001, \mathrm{P}=0.809$ & \\
\hline
\end{tabular}




\section{Figure Legends}

Fig. 1. Location of study areas in the vicinity of Lake Ontario, Canada (A). We compared wildcaught bluegill sunfish from a clean site (Lake Opinicon) (B) to those caught between Site 1 and Site 2 in Desjardins Canal, the receiving waters of the Dundas wastewater treatment plant (WWTP) (C). Effluent-containing water in Desjardins Canal flows into Cootes Paradise Marsh, a large and ecologically significant wetland at the western end of Lake Ontario. Using bluegill that had been wild-caught at Lake Opinicon, we also compared fish that were caged for 4 weeks at the contaminated site at Site 2 to fish that were similarly caged at a clean site (Beverley Swamp; located in the headwaters of Cootes Paradise Marsh, $17.4 \mathrm{~km}$ northwest of the WWTP). Map data: Google, DigitalGlobe. See Materials and Methods for additional methodological details.

Fig. 2. Wastewater exposure reduced survival of caged bluegill sunfish. Bluegill were wildcaught from a clean site, and were then caged for 4 weeks at either a clean reference site or downstream of the wastewater treatment plant. Data are shown as means $\pm \mathrm{SE}$. * represents significant difference in survival between fish from clean and contaminated sites (fixed effect of contaminant exposure, $\mathrm{Z}=-1.98, \mathrm{P}=0.047)$.

Fig. 3. Resting metabolic rates were increased by exposure to wastewater effluent in both wildcaught fish and caged fish. (A) Resting rates of $\mathrm{O}_{2}$ consumption $\left(\mathrm{MO}_{2}\right)$ (fixed effect of contaminant exposure, $\mathrm{F}=5.175, \eta^{2}=0.086,{ }^{*} \mathrm{P}=0.030$; caging, $\mathrm{F}=0.066, \eta^{2}=0.014, \mathrm{P}=0.799$; body mass, $\mathrm{F}=7.269, \eta^{2}=0.176, \mathrm{P}=0.011$ ). (B) Maximal $\mathrm{MO}_{2}$ (contaminant exposure, $\mathrm{F}=1.356$, $\eta^{2}=0.003, P=0.253$; caging, $F=0.068, \eta^{2}=0.025, P=0.796$; body mass, $F=25.298, \eta^{2}=0.445$, $\mathrm{P}<0.0001$ ). (C) Absolute aerobic scope, the difference between maximal $\mathrm{MO}_{2}$ and resting $\mathrm{MO}_{2}$ (contaminant exposure, $\mathrm{F}=0.0158, \eta^{2}=0.004, \mathrm{P}=0.901$; caging, $\mathrm{F}=0.402, \eta^{2}=0.034, \mathrm{P}=0.531$; body mass, $\mathrm{F}=9.137, \eta^{2}=0.225, \mathrm{P}=0.0051$ ). (D) Factorial aerobic scope, the quotient of maximal $\mathrm{MO}_{2}$ and resting $\mathrm{MO}_{2}$ (contaminant exposure, $\mathrm{F}=1.266, \eta^{2}=0.041, \mathrm{P}=0.269$; caging, $\mathrm{F}=0.538$, $\eta^{2}=0.014, \mathrm{P}=0.469$; body mass, $\left.\mathrm{F}=0.0002, \eta^{2}=0.000, \mathrm{P}=0.989\right)$. Data are shown as means $\pm \mathrm{SE}$. $\mathrm{N}$ are as follows: wild clean fish, 10; wild contaminated fish, 7; caged clean fish, 9; caged contaminated fish, 8 . 
Fig. 4. Organ masses were altered by exposure to wastewater effluent in wild-caught fish and caged fish. (A) Body mass (fixed effect of contaminant exposure, $\mathrm{F}=0.867, \eta^{2}=0.014, \mathrm{P}=0.356$; caging, $\mathrm{F}=0.068, \eta^{2}=0.001, \mathrm{P}=0.795$ ). (B) Brain mass expressed relative to body mass (contaminant $\times$ caging interaction, $\mathrm{F}=6.01, \eta^{2}=0.059$, ${ }^{*} \mathrm{P}=0.018$; body mass, $\mathrm{F}=8.98, \eta^{2}=0.073$, $\mathrm{P}=0.004$ ). (C) Liver mass expressed relative to body mass (contaminant exposure, $\mathrm{F}=15.40$, $\eta^{2}=0.085, * \mathrm{P}<0.001$; caging, $\mathrm{F}=0.96, \eta^{2}=0.003 \mathrm{P}=0.33$; body mass, $\mathrm{F}=46.20, \eta^{2}=0.408$, $\mathrm{P}<0.001$ ). (D) Heart mass expressed relative to body mass (contaminant exposure, $\mathrm{F}=10.99$, $\eta^{2}=0.039, * \mathrm{P}=0.0017$; caging, $\mathrm{F}=1.07, \eta^{2}=0.013, \mathrm{P}=0.306$; body mass, $\mathrm{F}=69.38, \eta^{2}=0.538$, $\mathrm{P}<0.0001)$. Data are shown as means $\pm \mathrm{SE}$. $\mathrm{N}$ are as follows: wild clean fish, 18; wild contaminated fish, 13; caged clean fish, 14; caged contaminated fish, 12.

Fig. 5. The effects of exposure to wastewater effluent on the activities of mitochondrial enzymes in the liver. (A) Cytochrome c oxidase (COX) activity per gram of liver tissue (fixed effect of contaminant exposure, $\mathrm{F}=0.02, \eta^{2}=0.001, \mathrm{P}=0.88$; caging, $\mathrm{F}=1.74, \eta^{2}=0.056, \mathrm{P}=0.20$; body mass, $\mathrm{F}=0.00, \eta^{2}=0.000, \mathrm{P}=0.98$ ). (B) COX activity per gram fish, calculated as the product of relative liver mass ( $\mathrm{g}$ liver per g body mass) and COX activity per gram of liver tissue (contaminant exposure, $\mathrm{F}=6.54, \eta^{2}=0.169 * \mathrm{P}=0.016$; caging, $\mathrm{F}=1.84, \eta^{2}=0.053, \mathrm{P}=0.185$ ). (C) Citrate synthase (CS) activity per gram of liver tissue (contaminant exposure, $\mathrm{F}=0.42, \eta^{2}=0.006, \mathrm{P}=0.52$; caging, $\mathrm{F}=0.72, \eta^{2}=0.014, \mathrm{P}=0.40$; body mass, $\mathrm{F}=2.12, \eta^{2}=0.065, \mathrm{P}=0.16$ ). (D) $\mathrm{CS}$ activity per gram fish (contaminant exposure, $\mathrm{F}=5.37, \eta^{2}=0.15, * \mathrm{P}=0.027$; caging, $\mathrm{F}=0.266, \eta^{2}=0.01, \mathrm{P}=0.61$ ). Data are shown as means \pm SE. $N$ are as follows: wild clean fish, 8; wild contaminated fish, 8; caged clean fish, 9; caged contaminated fish, 8 .

Fig. 6. The effects of exposure to wastewater effluent on the glycogen content of the liver. (A) Glycogen content per gram of liver tissue (fixed effect of contaminant exposure, $\mathrm{F}=4.86$, $\eta^{2}=0.144, * \mathrm{P}=0.039$; caging, $\mathrm{F}=0.503, \eta^{2}=0.013, \mathrm{P}=0.486$; body mass, $\mathrm{F}=3.93, \eta^{2}=0.138$, $\mathrm{P}=0.061$ ). (B) Glycogen content per gram fish, calculated as the product of relative liver mass ( $\mathrm{g}$ liver per g body mass) and glycogen content per gram of liver tissue (contaminant exposure, $\mathrm{F}=0.338, \eta^{2}=0.015, \mathrm{P}=0.567$; caging, $\left.\mathrm{F}=1.356, \eta^{2}=0.076, \mathrm{P}=0.257\right)$. Data are shown as means \pm SE. N are as follows: wild clean fish, 10; wild contaminated fish, 5; caged clean fish, 4; caged contaminated fish, 5 . 


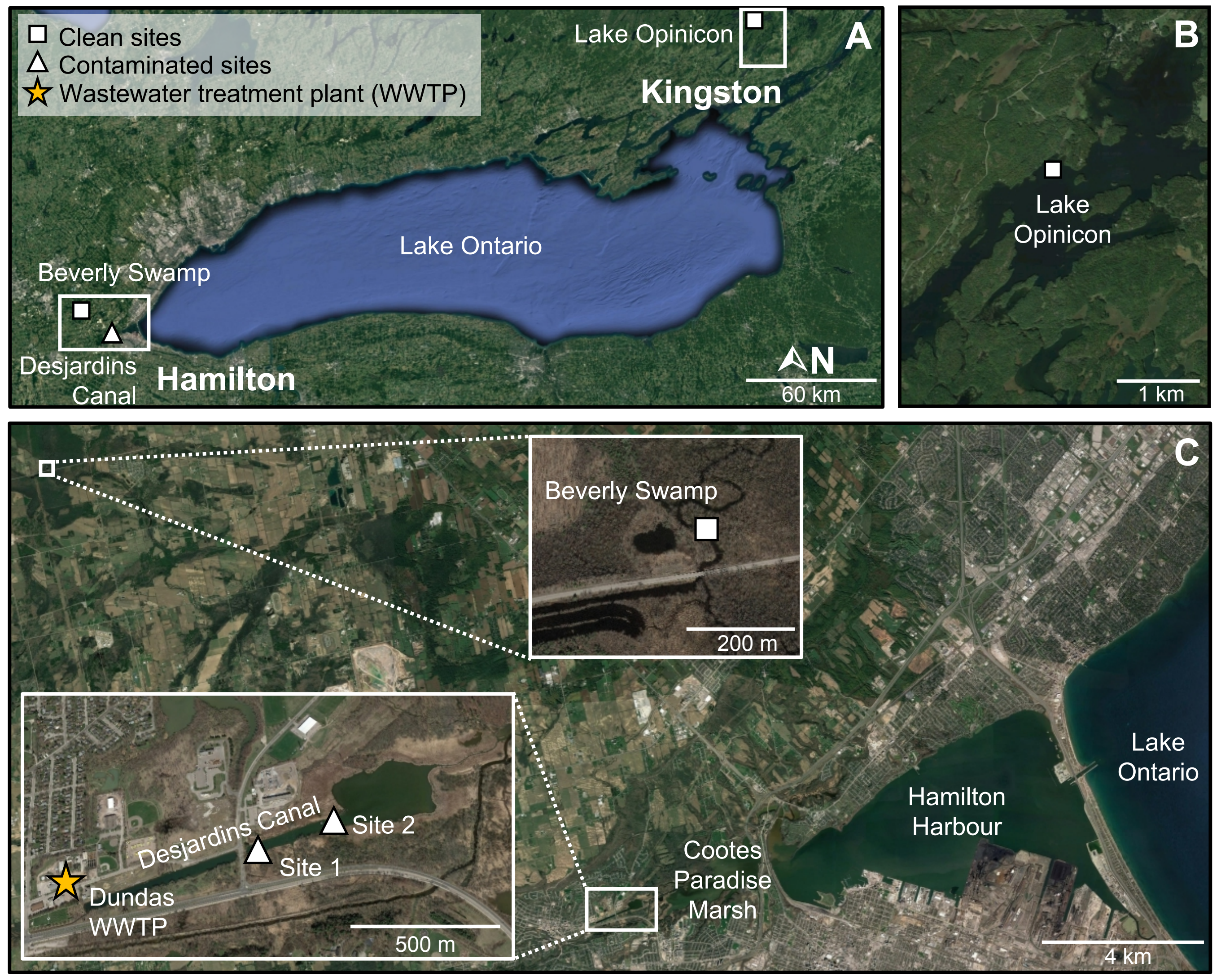




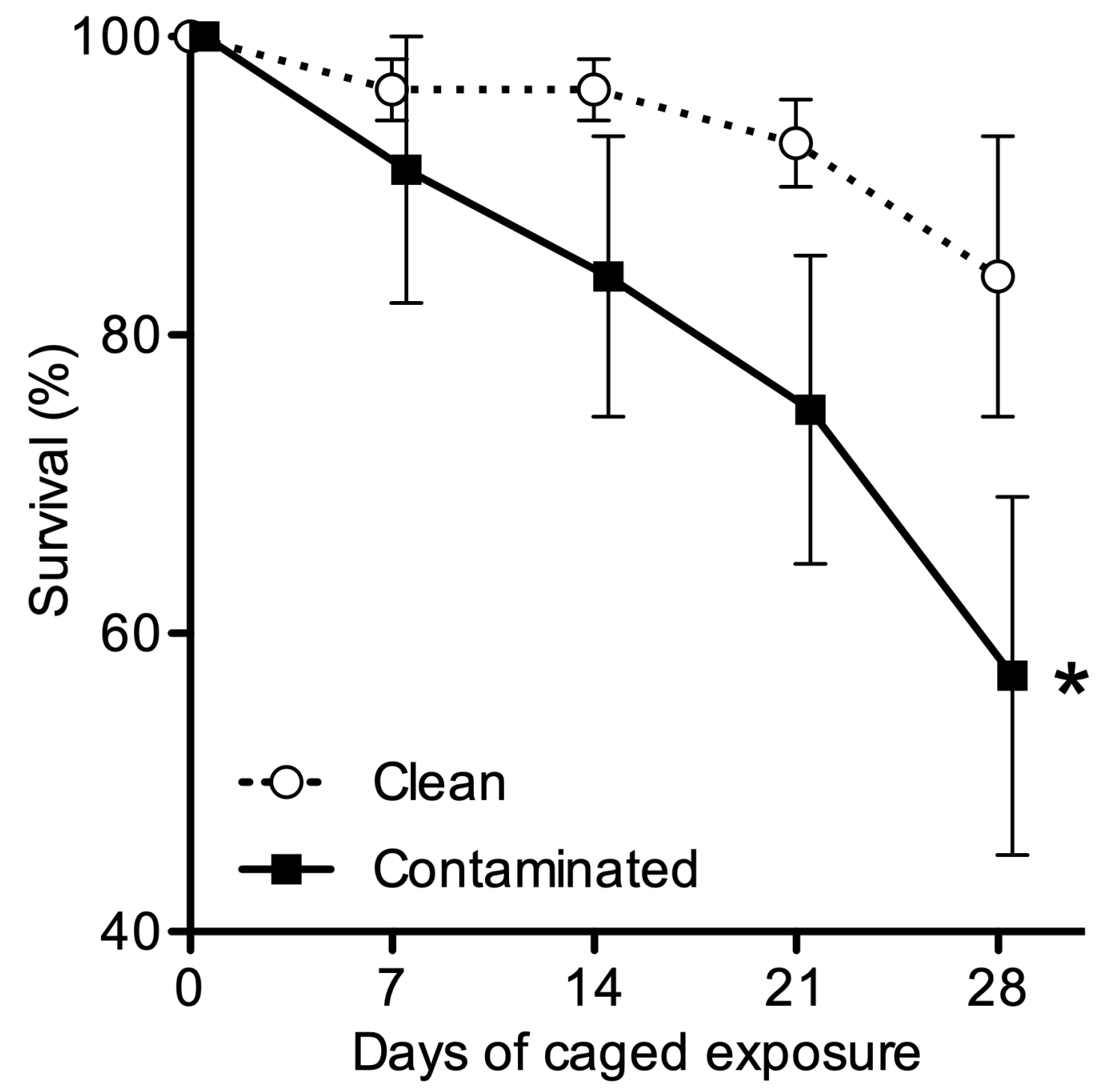




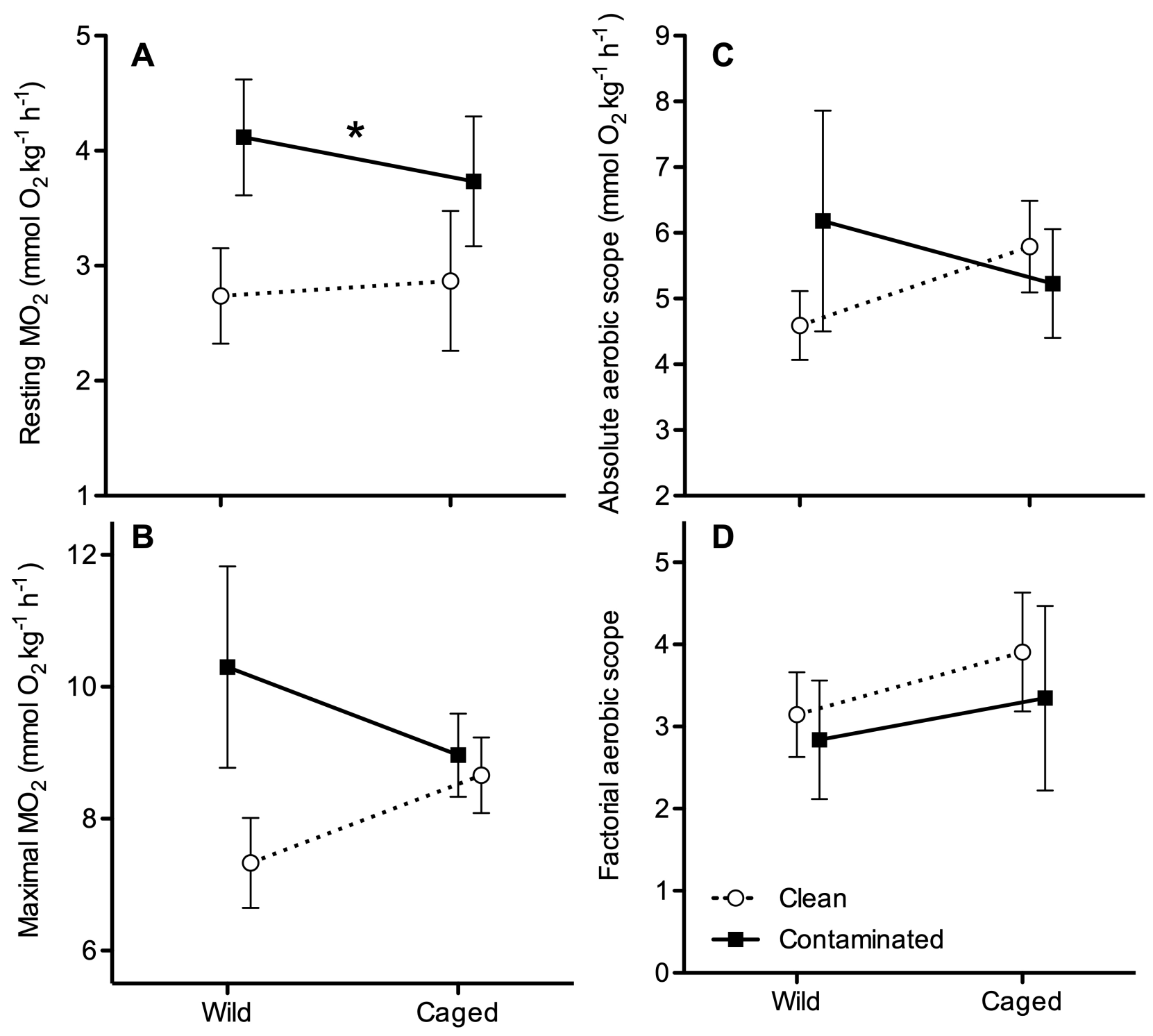



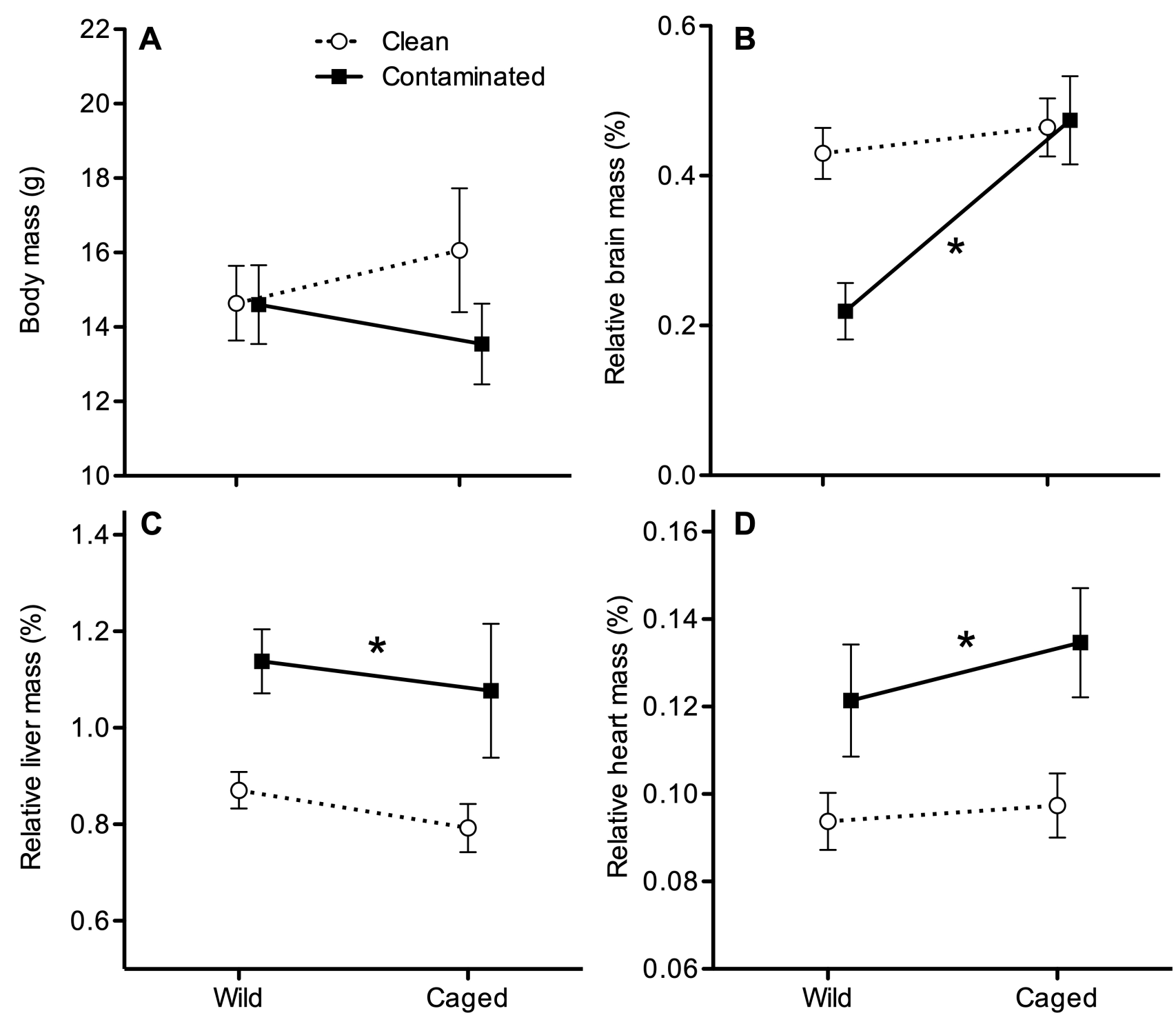

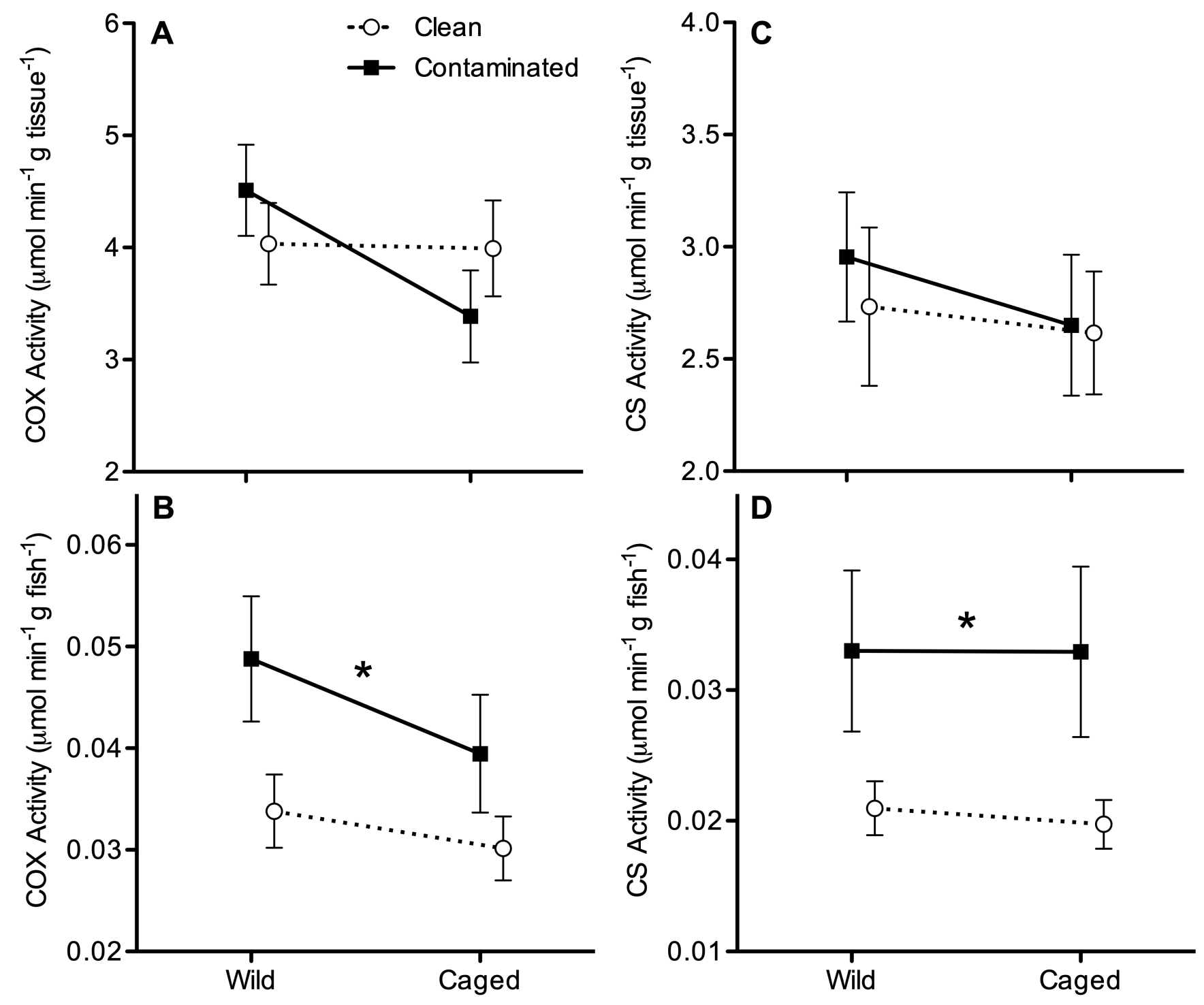

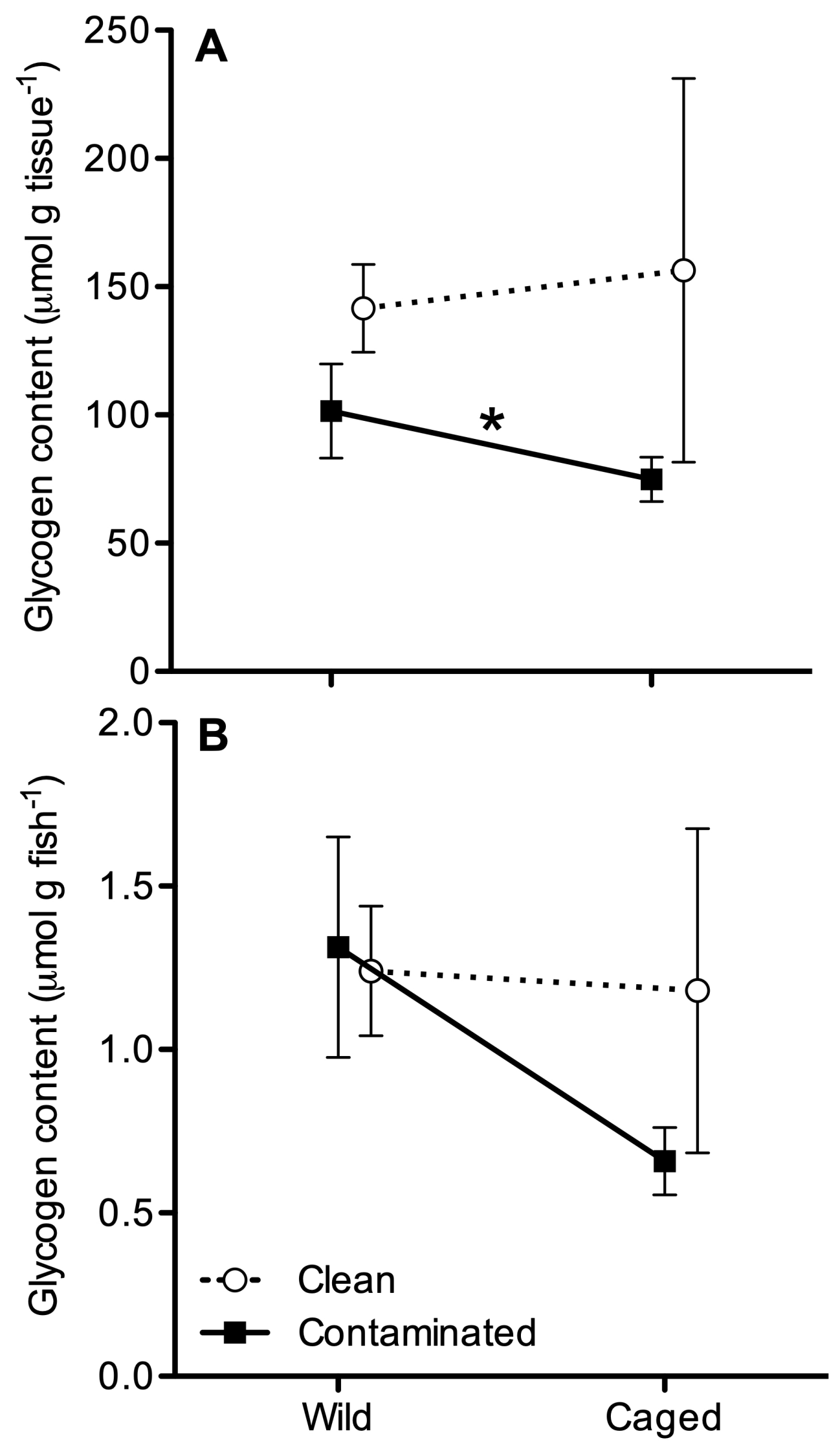


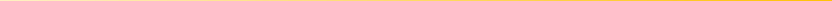

